\title{
Peripheral contributions to visceral hyperalgesia
}

\author{
GF Gebhart PhD
}

GF Gebhart. Peripheral contributions to visceral hyperalgesia. Can J Gastroenterol 1999;13(Suppl A):37A-41A. Hyperalgesia has long been recognized clinically as a consequence of tissue injury. Primary hyperalgesia (arising from the site of injury) is generally considered to be due to sensitization of sensory receptors (eg, nociceptors) and perhaps activation of so-called 'silent nociceptors' by mediators released, synthesized or attracted to the site of tissue injury. Key questions associated with understanding visceral hyperalgesia relate to whether the viscera are innervated by nociceptors (ie, sensory receptors that respond selectively to noxious intensities of stimulation), whether visceral receptors and/or afferent fibres sensitize after tissue injury and whether silent nociceptors exist in the viscera. Studies in nonhuman animals have revealed that hollow organs such as the esophagus, gall bladder, stomach, urinary bladder, colon and uterus are innervated by mechanically sensitive receptors with low or high thresholds for response. Accordingly, it appears that the viscera are innervated by nociceptors, although the issue is far from settled. One characteristic of cutaneous nociceptors is their ability to be sensitized when tissue is injured. Mechanosensitive visceral receptors also sensitize when the viscera are experimentally inflamed, but both visceral receptors with low thresholds and those with high thresholds for response are sensitized. Moreover, it is often not appreciated that visceral receptors are likely polymodal rather than unimodal - that is, mechanically sensitive visceral receptors typically are also sensitive to chemical and/or thermal stimuli. In this sense, visceral receptors may be considered evolutionarily older than more highly developed, specialized cutaneous receptors. Finally, there are mechanically insensitive receptors that innervate the viscera and, when tissue is injured, develop spontaneous activity and acquire sensitivity to mechanical stimuli. In the aggregrate, visceral receptors change their behaviour in the presence of tissue injury and, along with activated mechanically insensitive receptors, increase the afferent barrage into the spinal cord, contributing to the development of visceral hyperalgesia.

Key Words: Hyperalgesia, Irritable bowel syndrome, Nociceptors, Visceral receptors

\section{Contributions périphériques à l'hyperalgésie viscérale}

RÉSUMÉ : Sur le plan clinique, l'hyperalgésie a longtemps été reconnue comme la conséquence d'une atteinte tissulaire. L'hyperalgésie primaire (originant du siège d'une lésion) est en général considérée attribuable à la sensibilisation des récepteurs sensoriels (par ex., nocicepteurs) et peut-être à l'activation de présumés $<$ nocicepteurs silencieux $\gg$ par les médiateurs libérés, synthétisés ou mobilisés au siège de la lésion. Pour comprendre l'hyperalgésie viscérale, certaines grandes questions méritent qu'on s'y attarde : les viscères sont-elles innervées par des nocicepteurs (c.-à-d. des récepteurs sensoriels qui répondent sélectivement aux intensités nocives de certaines stimulations), les récepteurs viscéraux et/ou les fibres afférentes se sensibilisent-ils après une lésion tissulaire et les nocicepteurs silencieux sont-ils présents dans les viscères. Des études menées chez l'animal ont révélé que les organes creux, comme l'œsophage, la vésicule biliaire, l'estomac, la vessie, le côlon et l'utérus, sont innervés par des récepteurs mécanosensibles manifestant un seuil de réactivité bas ou élevé. Par conséquent, il semble que les viscères soient innervés par des nocicepteurs, bien que la question soit loin d'être réglée. L'une des caractéristiques des nocicepteurs cutanés est leur capacité de se sensibiliser lors d'une atteinte tissulaire. Les récepteurs mécanosensibles viscéraux se sensibilisent également lorsque les viscères sont expérimentalement soumis à l'inflammation, mais les récepteurs viscéraux sont sensibilisés en présence d'une lésion, que leur seuil de réactivité soit bas ou élevé. De plus, on oublie souvent que les récepteurs viscéraux sont plus susceptibles d'être polymodaux qu'unimodaux. C'est-à-dire que les récepteurs viscéraux mécanosensibles sont en général également sensibles aux stimuli chimiques et thermiques. En ce sens, les récepteurs viscéraux sont en général considérés plus anciens, sur le plan de l'évolution, que les récepteurs cutanés, plus sophistiqués et spécialisés. En terminant, des récepteurs mécano-insensibles innervent les viscères et, en présence d'une atteinte tissulaire, ils développent une activité spontanée et acquièrent une sensibilité aux stimuli mécaniques. Les récepteurs viscéraux regroupés changent de comportement en présence d'une atteinte tissulaire et avec les récepteurs mécano-insensibles activés, intensifient le barrage afférent dans la moelle épinière, ce qui contribue à l'hyperalgésie viscérale.

Department of Pharmacology, College of Medicine, University of Iowa, Iowa City, Iowa 52242-1109, USA

Correspondence and reprints: Dr GF Gebhart, Department of Pharmacology, University of Iowa College of Medicine, 2-471 Bowen Science

Building, Iowa City, Iowa 52242-1109, USA. Telephone 319-335-7946, fax 319-335-8930, e-mail gf-gebhart@uiowa.edu 
COPYRIGHT PULSUS GROUP

$\mathrm{T}$ he phenomenon of hyperalgesia has long been recognized clinically as a consequence of tissue injury, including damage to the nervous system. Cutaneous tenderness associated with abdominal and thoracic visceral disorders, termed 'referred pain', has also been appreciated for well over 100 years. Hyperalgesia is the general term that has been used to describe these enhanced pain sensations, although other terms (eg, hyperesthesia, allodynia, diffuse hyperalgesia) are or have also been used.

Hyperalgesia was defined by Hardy and colleagues (1) as an increase in pain produced by either a noxious stimulus or a normally non-noxious stimulus applied to peripheral tissue. This is illustrated in Figure 1 as a function relating stimulus intensity to pain sensation. As a consequence of tissue insult, the normal psychophysical function illustrated right-most in Figure 1 (labelled 'normal') is shifted leftward. As illustrated, noxious intensities of stimulation produce greater pain when tissue is injured, and previously innocuous intensities of stimulation can also produce pain (a phenomenon termed allodynia). There are, moreover, two types of hyperalgesia - that arising from the site of injury (primary hyperalgesia) and that demonstrable in uninjured tissue adjacent to the site of injury (secondary hyperalgesia).

Most studies in humans and nonhuman animals have focused on models of cutaneous and/or soft tissue injury when examining mechanisms of hyperalgesia; more recently, models of neuropathic pain have also been studied. Notwithstanding documentation 25 years ago that the psychophysical function relating volume of colon distension to pain sensation was shifted leftward in irritable bowel syndrome patients (Figure 2), it has only been relatively recent that visceral hyperalgesia has become a focus of study (reviewed in 2,3). Accordingly, most of what is known about mecha-

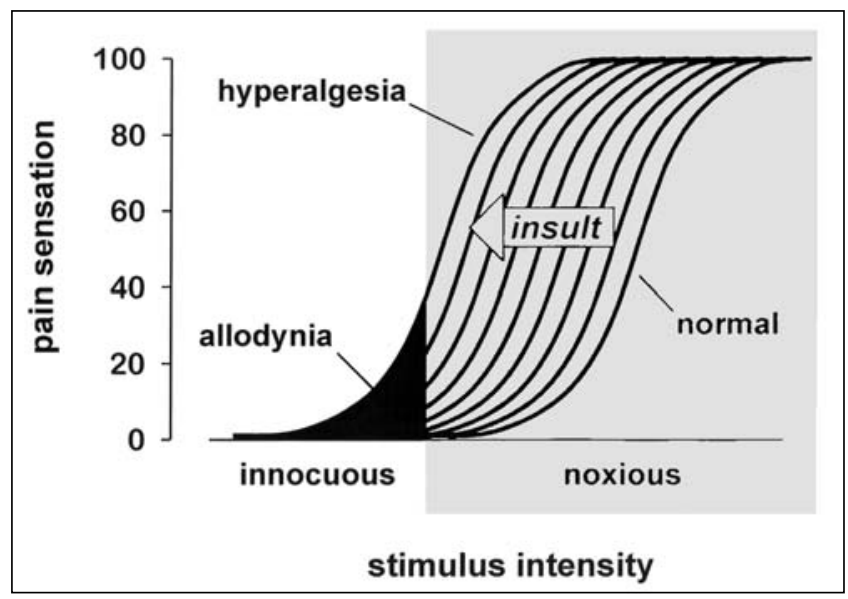

Figure 1) Relationship between stimulus intensity and sensation. In the absence of tissue insult, the function labelled 'normal' illustrates that pain is associated only with noxious intensities of stimulation. In the presence of an insult to tissue, this function shifts leftward and the same intensities of noxious stimulation produce greater pain. Note also that innocuous intensities of stimulation can also acquire the ability to give rise to pain after tissue injury. Adapted and modified with permission from reference 15
NG. $=00$ NOT COPY

nisms of hyperalgesia has been derived from studies of cutaneous models of hyperalgesia.

Lewis (4) was the first to study systematically the mechanisms of hyperalgesia, concluding that both primary and secondary hyperalgesia arose by peripheral mechanisms. Hardy and coworkers (1) first suggested, and subsequent investigations have confirmed (5), that secondary hyperalgesia results from an increase in the excitability of spinal neurons (termed 'central sensitization' [6]). Documentation in the 1960s by Perl (reviewed in 7) that cutaneous nociceptors are sensitized by tissue injury (and that non-nociceptors are not sensitized) led to rapid acceptance that such change in the behaviour of nociceptors was the basis of primary hyperalgesia at the site of injury. Presently, it is generally considered that primary hyperalgesia is due to sensitization of nociceptors (and perhaps activation of so-called 'silent nociceptors' [8]) by mediators released, synthesized or attracted to the site of tissue injury. Secondary hyperalgesia is considered to arise in the spinal cord dorsal horn, triggered by the increased barrage of afferent input and consequent increased release of the neuroactive contents from the primary afferent nerve terminals (eg, glutamate and substance $\mathrm{P})$.

The present article focuses on the potential peripheral afferent (sensory) contributions to the development of visceral hyperalgesia. Given the brief overview above, the following questions arise. Are the viscera (such as skin, muscle and joints) innervated by nociceptors (ie, sensory receptors that respond selectively to noxious intensities of stimulation)? Do visceral afferent fibres (nociceptors) sensitize when the viscus is insulted (as when inflamed experimentally)? Do mechanically insensitive ('silent') fibres exist in the viscera?

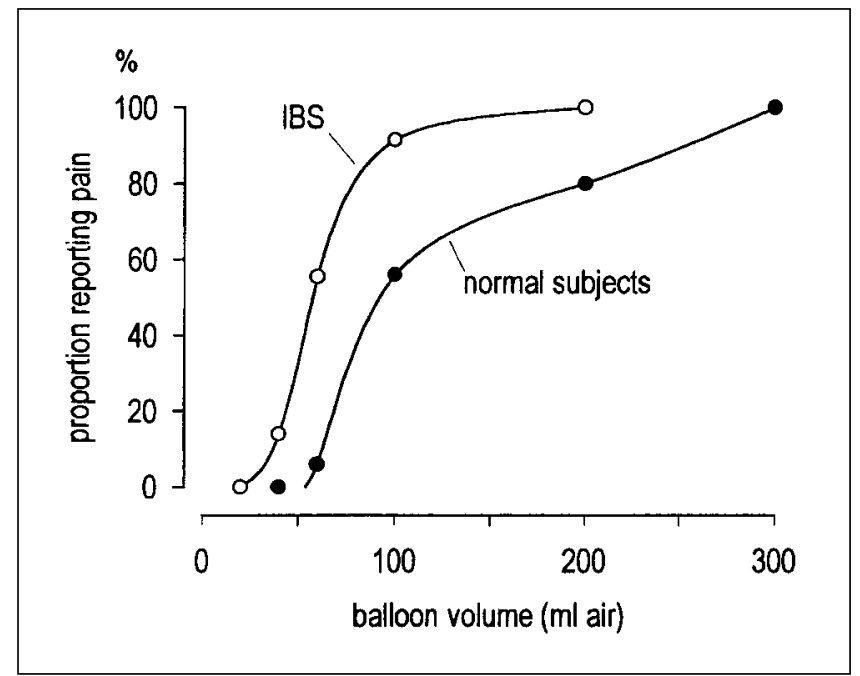

Figure 2) Pain from balloon distension of the pelvic colon in normal subjects and those with irritable bowel syndrome (IBS). This psychophysical function, as with that illustrated in Figure 1, shows a leftward shift in IBS patients compared with normal subjects. Adapted with permission from reference 16 


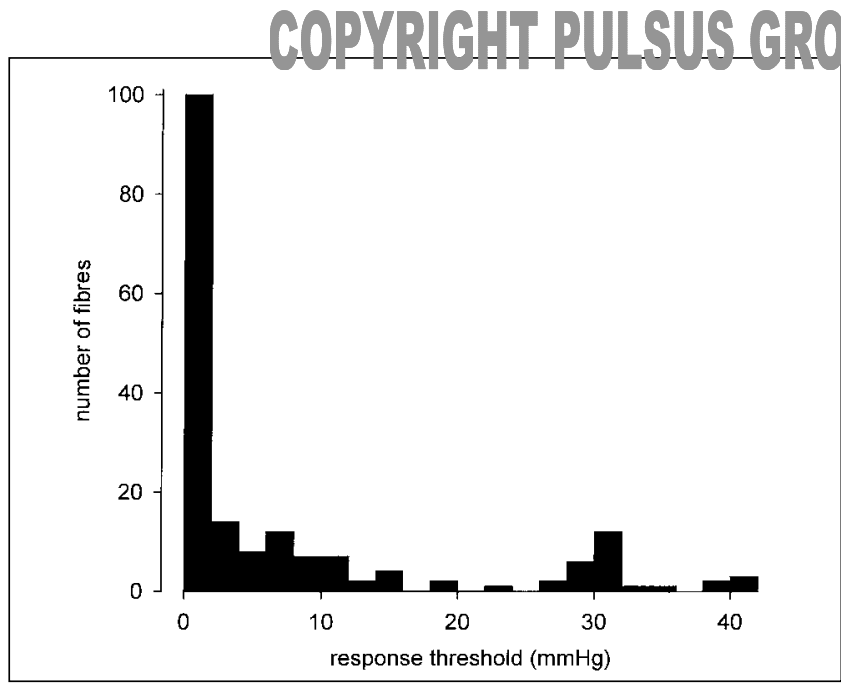

Figure 3) Frequency histogram of extrapolated response thresholds of rat pelvic nerve afferent fibres recorded in the S1 dorsal root to colorectal distension. Data from references 11 and 13

\section{VISCERAL NOCICEPTORS}

The functional classification of visceral afferent fibres and their associated receptors as nociceptors has been an issue of some disagreement. Most studies of visceral pain mechanisms have used mechanical distension of hollow organs to reproduce natural stimuli that activate mechanoreceptors. For example, balloon distension of the gut produces sensations similar in intensity, quality and localization to those experienced with functional bowel disorders and, thus, represents an appropriate stimulus for experimental use. It was long argued that visceral pain arises from both spatial and temporal summation of sensory information arising from a homogeneous population of spinal afferent fibres. Over the past 10 to 15 years, however, it has been well documented that the hollow viscera are innervated by two distinct populations of mechanosensitive afferent fibres. Approximately $20 \%$ to $25 \%$ of visceral afferent fibres studied have high thresholds for mechanical distension, responding only to noxious intensities of stimulation. Such fibres encode the intensity of stimulation only in the noxious range and, thus, appear to be analogous to receptors in skin classed as nociceptors. Thus, they are thought to subserve a similar nociceptive function in the viscera. A greater proportion of visceral afferent fibres (approximately 75\%) have thresholds for activation by mechanical distension in the physiological range ( $5 \mathrm{mmHg}$ or less) and encode the intensity of stimulation throughout both the non-noxious and noxious ranges of stimulation (reviewed in 9). Figure 3 shows a frequency distribution histogram of response thresholds of pelvic nerve afferent fibres innervating the colon of the rat, clearly showing different populations of afferent fibres categorized on the basis of response threshold.

Thresholds for response to either thermal or mechanical stimuli are used, in part, to characterize cutaneous receptors as nociceptors. Perhaps more important than response threshold, however, is consideration of the encoding properties of these receptors. Quantitative evaluation of responses

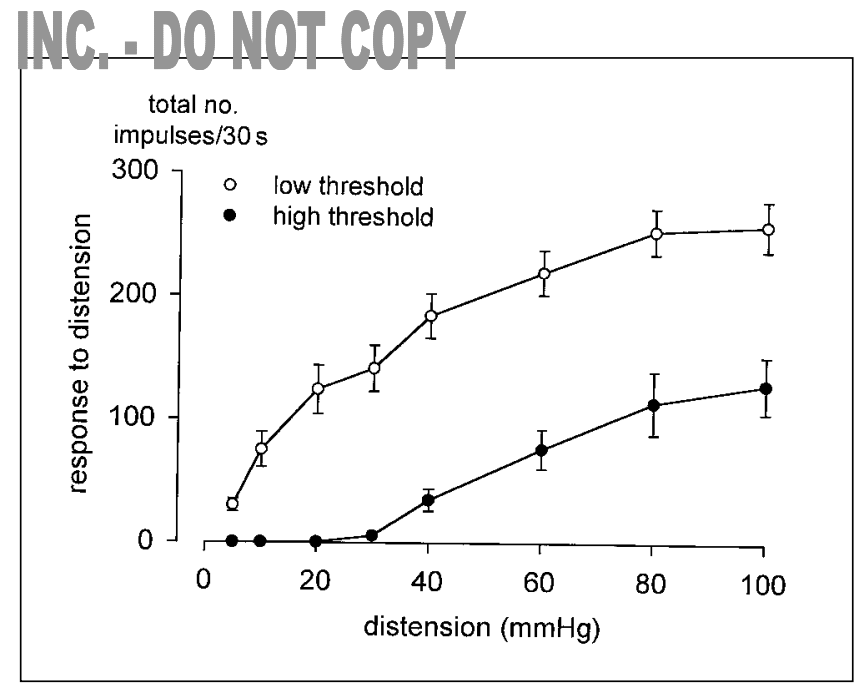

Figure 4) Encoding properties of low and high threshold mechanosensitive pelvic nerve afferent fibres to graded intensities of colorectal distension in the rat. Data from references 11 and 13

of mechanosensitive visceral afferent fibres to graded distension of hollow organs reveals that afferent fibres with low thresholds exhibit encoding properties similar to those of fibres with high thresholds and, moreover, exhibit greater response magnitude at all intensities of distension studied (Figure 4).

Accordingly, it is difficult to argue that visceral afferent fibres with high thresholds for response to mechanical distension are nociceptors (because low threshold fibres also encode in the noxious range and give greater magnitude responses). Rather, it is becoming clear that the entire population of mechanosensitive afferent fibres innervating the viscera likely contribute to nociceptive input to the spinal cord; therefore, one may think of all mechanosensitive afferent fibres as nociceptors. An interesting characteristic of the mechanosensitive afferent fibres that innervate the gut (shared with a subset of cutaneous nociceptors) is that they typically also respond to other modalities of stimulation. They are polymodal in character and all likely respond to at least two modalities of stimulation; many respond to mechanical, thermal and chemical stimulation. In a study of 50 mechanosensitive pelvic nerve afferent fibres innervating the colon of the rat, 20 also responded to a chemical stimulus and 36 also responded to a thermal stimulus (all stimuli were applied to the mucosal surface in vivo); 16 of 50 fibres responded to all three modalities of stimulation (10).

\section{SENSITIZATION OF AFFERENT FIBRES}

Cutaneous polymodal nociceptors are characterized in part by their ability to become sensitized when tissue is injured (this constitutes an important contribution to the development of cutaneous hyperalgesia). It is noteworthy that among the receptors present in skin, only nociceptors exhibit the ability to sensitize. Because it is now clear that visceral afferent fibres with both low and high thresholds for response to mechanical distension can be sensitized by experimental inflammation, the argument that all mechano- 


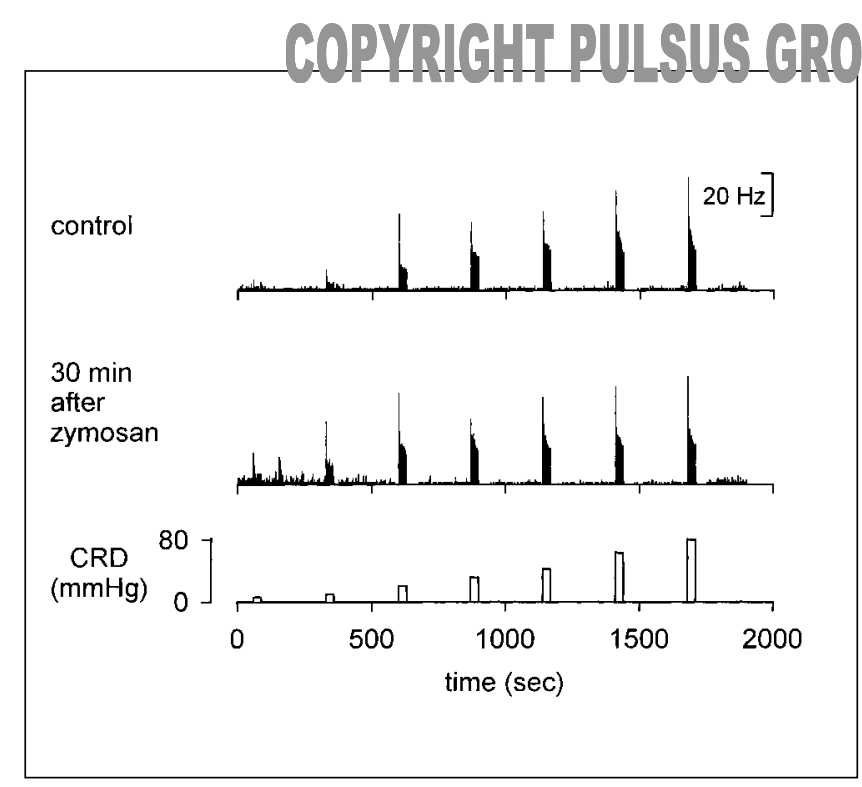

Figure 5) Example of a low threshold mechanosensitive pelvic nerve afferent fibre before (top row of peristimulus time histograms) and 30 mins after instillation of zymosan intracolonically (bottom row of peristimulus time histograms). The intensity of colorectal distension (CRD) is illustrated bottom-most (unpublished data)

sensitive visceral afferent fibres likely contribute to visceral nociception is strengthened. Figure 5 illustrates sensitization of a low threshold, mechanosensitive pelvic nerve afferent fibre innervating the colon of the rat. Typically, experimental inflammation (in this case produced by intracolonic instillation of zymosan) leads to an increase in background activity and an increase in response magnitude to mechanical distension of the colon, particularly at the lower pressures of distension. In fibres with high thresholds for response to distension, response threshold is typically reduced and both background activity and response magnitude increase. In several laboratory studies (11-13), mechanosensitive pelvic nerve afferent fibres innervating the urinary bladder or the colon have been shown to be reliably sensitized by a variety of irritants instilled into the urinary bladder (xylenes, turpentine) or colon (mustard oil, acetic acid, trinitrobenzine sulphonic acid, zymosan). To date, all high threshold pelvic nerve afferent fibres studied have been sensitized by experimental inflammation, and most low threshold fibres have also been similarly sensitized by the same manipulations. That not all low threshold afferent fibres are sensitized may relate to the concentration of the irritant or to other characteristics of these receptors that are not yet understood.

The relationship between sensitization of afferent fibres innervating the gut and visceral hyperalgesia should be clear. In the presence of an insult to the tissue, the background activity of these afferent fibres increases, and responses to mechanical stimulation (eg, produced by changes in motility or by filling) are increased, apparently more so at the lower intensities of distension in the physiological range (which would not normally be sensed). The response thresholds of the smaller population of afferent fibres with high thresholds for mechanical distension are decreased in the presence of tissue insult and, accordingly, begin to respond within the

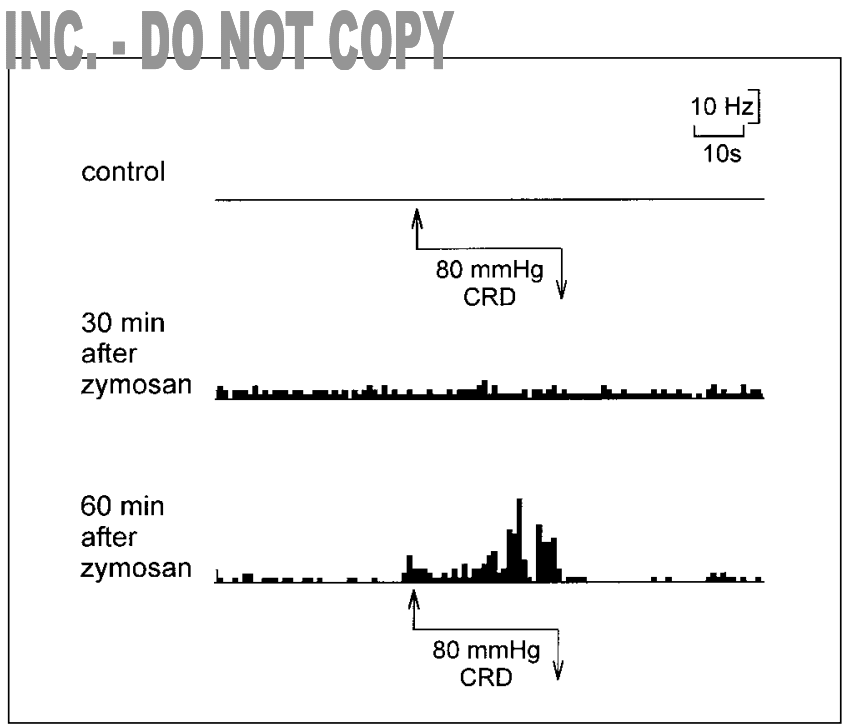

Figure 6) Example of a mechanically insensitive pelvic nerve afferent fibre innervating the colon of the rat. Shown at the top is the absence of response to a noxious intensity of colorectal distension (CRD) $(80 \mathrm{mmHg}$, $30 \mathrm{~s}$ ). After intracolonic instillation of zymosan, this afferent fibre became spontaneously active and also acquired sensitivity to colorectal distension (unpublished data)

physiological range of mechanical stimuli. Such changes in the behaviour of the afferent innervation of a viscus clearly lead to an enhanced input to the spinal cord and likely to altered sensations.

\section{MECHANICALLY INSENSITIVE AFFERENT FIBRES}

Another relatively newly appreciated group of fibres are also affected by tissue insult. Initially termed 'silent' or 'sleeping' nociceptors, mechanically insensitive visceral afferent fibres become sensitive to mechanical stimuli after tissue is inflamed. Such fibres, first described in the afferent innervation of the knee joint of the cat (8), have no background activity and are unresponsive, even to noxious intensities of mechanical stimulation. After experimental inflammation, however, these previously silent afferent fibres become spontaneously active and acquire sensitivity to mechanical stimulation (Figure 6).

Mechanically insensitive afferent fibres in the viscera are experimentally difficult to find; therefore, there are limited examples in the literature. It is estimated, however, that approximately $30 \%$ to $35 \%$ of afferent fibres in the pelvic nerve of the rat are mechanically insensitive (14). Thus, these fibres have the potential to contribute significantly to altered sensations associated with insult to the gut. It should be appreciated, however, that the proportion of mechanically insensitive afferent fibres that innervate the viscera is likely overestimated because the adequate stimulus for many, if not most, visceral afferent fibres is unknown. This circumstance arises principally because mechanical distending stimuli have been used by most investigators, who often do not also test other stimuli to determine whether the receptor is also chemosensitive and/or thermosensitive or truly mechanically insensitive. 


\section{COPYRIGHT PULSUS GROUP
CONCLUSIONS}

The most parsimonious response to the question of whether the viscera are innervated by nociceptors is that all mechanically sensitive afferent fibres innervating hollow organs likely contribute to transmission of nociceptive information. This conclusion derives in part from evidence documenting that visceral afferent fibres with low and high thresholds for response to mechanical distension can be sensitized by experimental inflammation and that most mechanically sensitive visceral afferent fibres are also responsive to chemical and/or thermal stimuli. Finally, the potential contribution of so-called silent nociceptors is clear, but the proportion of such fibres among the afferent innervation of the viscera is unknown at present.

Although our knowledge of visceral receptors and visceral sensation has increased significantly in recent years, the focus experimentally on mechanosensitivity leaves several issues unresolved. Most visceral receptors are polymodal and, presumably, when sensitized not only exhibit altered responses to mechanical stimulation, but also likely respond differently to chemical and/or thermal stimuli. The significance of such multimodal signal transduction by visceral receptors to altered gut sensations in patients with functional bowel disorders is obvious. Clinical experience documents that visceral inflammation is associated with pain in response to stimuli that are not normally painful and that those altered sensations must arise, at least initially, from alterations in the properties of visceral afferent fibres and their receptors in the viscera.

ACKNOWLEDGEMENTS: The excellent secretarial assistance of Susan Birely and production of graphics by Michael Burcham are gratefully acknowledged. The author is supported by National Institutes of Health awards NS 19912 and DA 02897.
REFERENCES $\mathrm{NO}$

1. Hardy JD, Wolff HG, Goodell H. Experimental evidence on the nature of cutaneous hyperalgesia. J Clin Invest 1950;29:115-40.

2. Gebhart GF. Visceral pain mechanisms. In: Chapman CR, Foley KM, eds. Current and Emerging Issues in Cancer Pain: Research and Practice. New York: Raven Press, 1993:99-111.

3. Mayer EM, Gebhart GF. Functional bowel disorders and visceral hyperalgesia. Gastroenterology 1994;107:271-93.

4. Lewis T. Pain. London: MacMillan, 1942.

5. LaMotte RH, Shain CN, Simone DA, Tsai E-F. Neurogenic hyperalgesia: psychophysical studies of underlying mechanisms. J Neurophysiol 1991;66:190-211.

6. Woolf CJ. Excitability changes in central neurons following peripheral damage. In: Willis WD, ed. Hyperalgesia and Allodynia. New York: Raven Press, 1992:221-43.

7. Perl ER. Pain and the discovery of nociceptors. In: Belmonte C, Cervero F, eds. Neurobiology of Nociceptors. Oxford: Oxford University Press, 1996:5-36.

8. Schaible H-G, Schmidt RF. Time course of mechanosensitivity changes in articular afferents during a developing experimental arthritis. J Neurophysiol 1988;60:2180-95.

9. Sengupta JN, Gebhart GF. Mechanosensitive afferent fibers in the gastrointestinal and lower urinary tracts. In: Gebhart GF, ed. Visceral Pain. Seattle: IASP Press, 1995:75-98.

10. Su X, Gebhart GF. Mechanosensitive pelvic nerve afferent fibers innervating the colon of the rat are polymodal in character. J Neurophysiol 1998;80:2632-44.

11. Sengupta JN, Su X, Gebhart GF. $\kappa$, but not $\mu$ or $\sigma$, opioids attenuate responses to distension of afferent fibers innervating the rat colon. Gastroenterology 1996;111:968-80.

12. Su X, Sengupta JN, Gebhart GF. Effects of opioids on mechanosensitive pelvic nerve afferent fibers innervating the urinary bladder of the rat. J Neurophysiol 1997;77:1566-80.

13. Su X, Sengupta JN, Gebhart GF. Effect of kappa opioid receptor-selective agonists on responses of pelvic nerve afferents to noxious colorectal distension. J Neurophysiol 1997;78:1003-12.

14. Sengupta JN, Gebhart GF. Characterization of mechanosensitive pelvic nerve afferent fibers innervating the colon of the rat. J Neurophysiol 1994;71:2046-60.

15. Cervero F, Laird JMA. Mechanisms of touch-evoked pain (allodynia): a new model. Pain 1996;68:13-23.

16. Ritchie J. Pain from distension of the pelvic colon by inflating a balloon in the irritable colon syndrome. Gut 1973;14:125-32. 


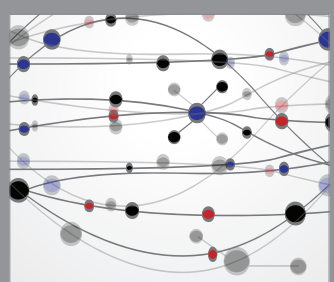

The Scientific World Journal
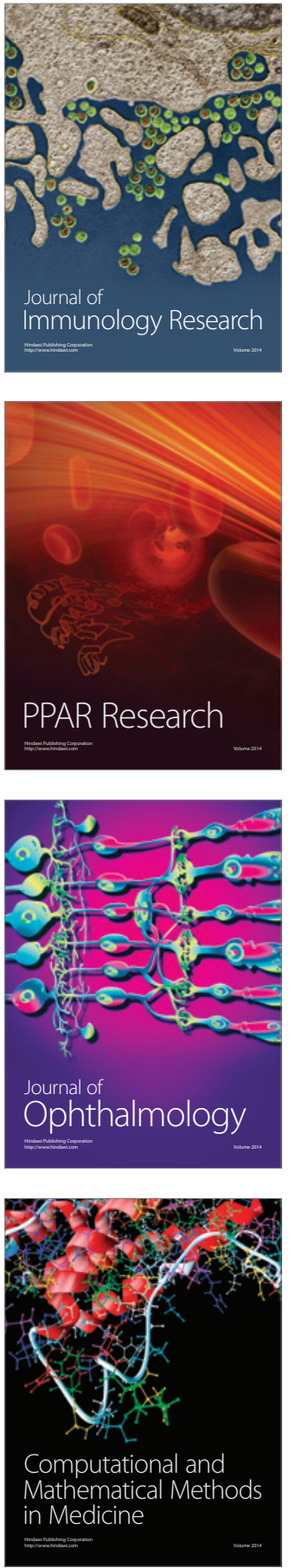

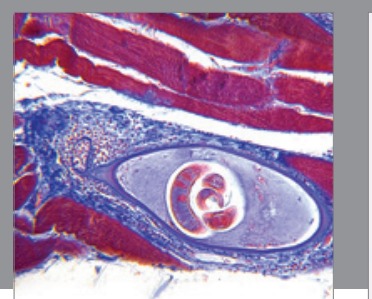

Gastroenterology Research and Practice

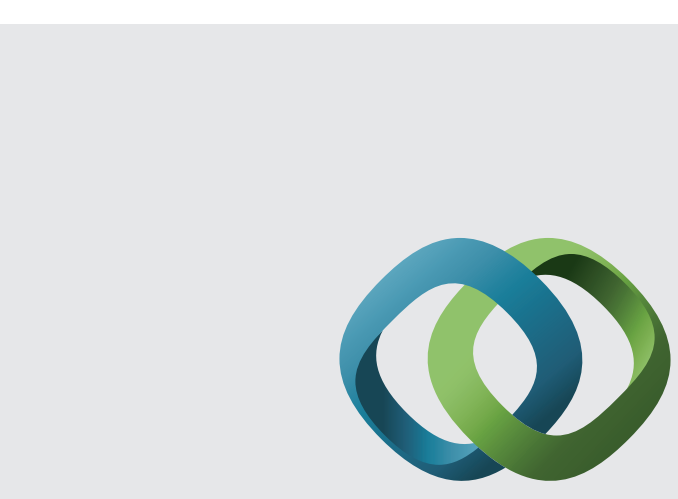

\section{Hindawi}

Submit your manuscripts at

http://www.hindawi.com
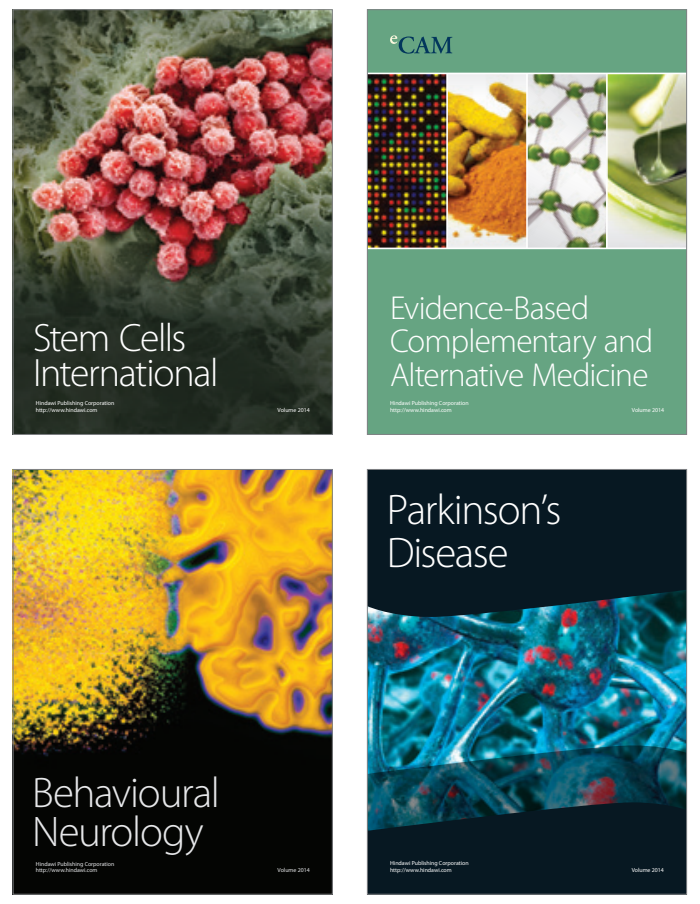
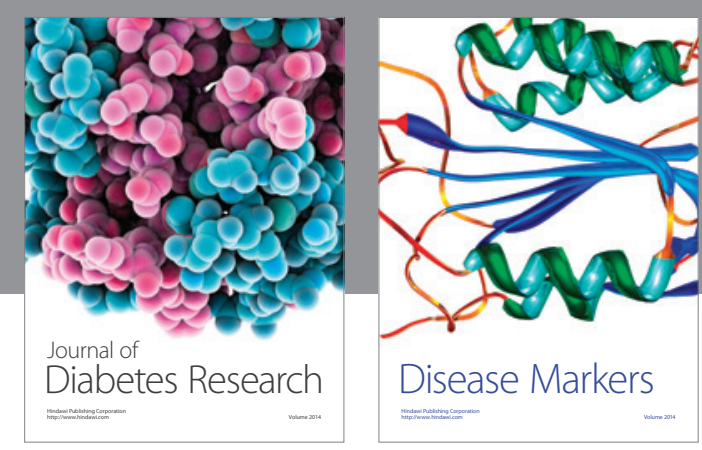

Disease Markers
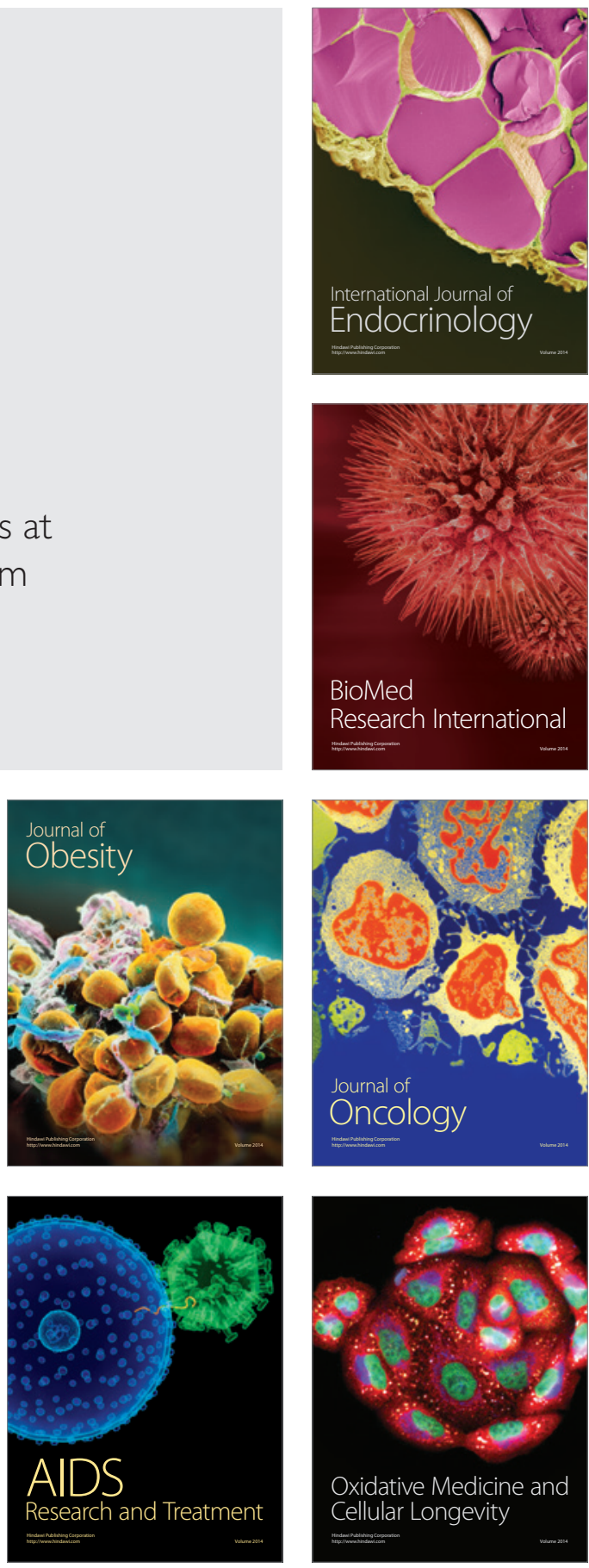